\title{
Agrobacteria Enhance Plant Defense Against Root-Knot Nematodes on Tomato
}

\author{
Janja Lamovšek, Barbara Gerič Stare, Irena Mavrič Pleško, Saša Širca, and Gregor Urek
}

Agricultural Institute of Slovenia, Plant Protection Department, Hacquetova ulica 17, SI-1000 Ljubljana, Slovenia. Accepted for publication 26 January 2017.

\begin{abstract}
The increased incidence of the crown gall disease caused by Agrobacterium tumefaciens has long been associated with activities of root-knot nematodes (Meloidogyne spp.). Pot experiments on tomato were designed to assess plant vitality, nematode reproduction, and crown gall incidence in combined infection with Agrobacterium and Meloidogyne spp. on tomato roots. Results suggest that tomato plants infected with pathogenic A. tumefaciens 2 days before the nematodes show enhanced plant defense against $M$. ethiopica resulting in lower egg and gall counts on roots 45 and 90 days postinoculation (dpi); no significantly enhanced defense was observed when the plant was inoculated with bacteria and nematodes at the

same time. Split-root experiments also showed that the observed interaction was systemic. Reverse-transcription quantitative polymerase chain reaction analysis that targeted several genes under plant hormonal control suggests that the suppression was mediated via systemic acquired resistance by the pathogenesis-related protein 1 and that $M$. ethiopica did not enhance the defense reaction of tomato against Agrobacterium spp. Nematodes completely inhibited tumor growth in a 45-day experiment if inoculated onto the roots before the pathogenic bacteria. We conclude that the observed antagonism in the tested pathosystem was the result of initially strong plant defense that was later suppressed by the invading pathogen and pest.
\end{abstract}

Combined infection of crown gall-causing bacteria (e.g., Agrobacterium spp.) and root-knot nematodes (RKN) (Meloidogyne spp.) results in increased frequency and severity of crown gall disease (Rubio-Cabetas et al. 2001) and stimulated RKN reproduction (ElSherif and Elwakil 1991) on host plants. However, no consensus exists as to whether synergism of the pest and pathogen or an additive effect is responsible for the increased disease phenotype. Although RKN evade and modify host defense (Smant and Jones 2011), pathogenic or nonpathogenic bacteria may activate pathogen-associated molecular pattern (PAMP)-triggered immunity (PTI) (Jones and Dangl 2006), and most phytopathogenic bacteria suppress plant-related immune responses (Abramovitch et al. 2006).

The hypothesis of the synergism in the AgrobacteriumMeloidogyne pathosystem is based on reports from several authors that observed a positive correlation between the incidence of crown gall and the incidence of galling induced by RKN. Griffin et al. (1968) noticed higher incidence of raspberry crown gall when RKN were present in the soil. Similar observations were made by Orion and Zutra (1971) and Zutra and Orion (1982) on almond and cotton, Dhanvantari et al. (1975) on peach, Süle et al. (1995) on grapevine, and Rubio-Cabetas et al. (2001) on Prunus cerasifera. In a split-root experiment, Agrobacterium tumefaciens stimulated reproduction and development of Meloidogyne incognita in parts of tomato roots accessible only to the nematodes (El-Sherif and Elwakil 1991). Synergism was also inferred when Karimi et al. (2000) demonstrated that RKN transported agrobacteria into the roots that resulted in an increased transformation frequency of T-DNA from agrobacteria. In two reports, however, authors observed nonsynergistic effects of nematodes and bacteria. Fakhouri et al. (1996) described reduced disease symptoms with combined infection on tomato after 90 days, and El-Beltagi et al. (2011) showed that A. tumefaciens reduced $M$. incognita gall and egg production on grapevine roots after 1 year.

Agrobacteria and RKN cause damage on numerous plant species worldwide. Crown gall is economically more important on woody

Corresponding author: J. Lamovšek; E-mail address: janja.lamovsek@kis.si

(C) 2017 The American Phytopathological Society hosts such as nut and fruit trees (Epstein et al. 2008; Kennedy and Alcorn 1980) and polyphagous RKN can significantly reduce crop yields in vegetables within one growing season (Nicol et al. 2011). M. ethiopica caused significant damage on grapevine, actinidia, and potato crops in Chile (Carneiro et al. 2007) and was detected for the first time in 2003 in Slovenia under sub-Mediterranean climate conditions (Širca et al. 2004). Later, it was also discovered in Greece (Conceição et al. 2012) and Turkey (Aydınlı et al. 2013). RKN and crown-gall bacteria are difficult to control because efficient and environmentally friendly management strategies are limited. Recently, it has been recognized that soils accommodating a high microbial diversity possess high suppressiveness against RKN (Adam et al. 2014), with different rhizobacteria known to antagonize RKN (Aballay et al. 2013; Hallmann et al. 2001, 2009; Martinuz et al. 2013; Radwan et al. 2012; Siddiqui et al. 2007). In addition, rhizobacteria, mycorrhizal fungi, bioproducts of microbial origin, and derivatives of salicylic acid (SA) and jasmonic acid (JA) can induce resistance against various pathogens (Bakker et al. 2007; Fujimoto et al. 2011; Van Wees et al. 2008; Yan et al. 2002).

Plant defense is activated as soon as the host recognizes an invading pathogen. This first and basal line of defense is activated upon recognition of the PAMP and leads to PTI. PTI is part of the innate immune system and associated, among others, with early oxidative burst (ROS), defense gene induction, and callose deposition on the cell walls (Jones and Dangl 2006; Zipfel 2009). Many rhizobacteria trigger PTI and resistance-inducing mechanisms such as systemic acquired (SAR) and induced systemic resistance (ISR) (Jones and Dangl 2006; Van Wees et al. 2008). Rhizobacteria-induced ISR is manifested in upregulation of JA- and ethylene (ET)-controlled genes (Van der Ent et al. 2009). To overcome plant defense, pathogenic agrobacteria have evolved systems to suppress plant defense mechanisms to effectively integrate a segment of a tumor-inducing plasmid (Ti) called T-DNA into the plant genome (Lee et al. 2009; Veena et al. 2003; Xu and Pan 2000). The underlying mechanism was identified as a rapid local plant defense gene suppression on Arabidopsis thaliana (Ditt et al. 2006; Lee et al. 2009) and Nicotiana tabacum (Veena et al. 2003) and on cultured cells of Ageratum conyzoides (Ditt et al. 2005). Expression of bacterial tumorigenic genes may disturb plant hormonal balances, enabling uncontrolled division of 
transformed cells and tumor growth (Veselov et al. 2003). According to the model of Veena et al. (2003), the strength of plant defense rises again after Agrobacterium spp. had successfully transformed the plant cells. This model can explain why SA, albeit known to enhance plant's resistance to Agrobacterium (Anand et al. 2008), was found in tumors (Deeken et al. 2006; Lee et al. 2009).

Local plant defense is also suppressed by RKN that are known to modulate host immune responses. Infective second-stage juveniles secrete proteins designed to evade, prevent, and manipulate host defense mechanisms during root penetration and feeding site formation (Davis et al. 2008; Dubreuil et al. 2011; Jaubert et al. 2002). However, host resistance genes in tomato may recognize nematode effectors and activate an effector-triggered immunity (ETI) response, resulting in strong hypersensitive-like reactions against the pest (Smant and Jones 2011). Evidence for the suppression of the PTI or ETI signaling by RKN is slowly emerging. Two recent studies suggest that $M$. incognita and $M$. javanica nematodes secrete effector proteins interfering with the host PTI response (Jaouannet et al. 2013; Lin et al. 2016).

The research presented here aims at (i) determining the nature of the Agrobacterium-Meloidogyne interaction (synergistic versus antagonistic) in biological tests on a susceptible tomato hybrid and (ii) measuring the involvement of the systemic plant response in split-root experiments. To determine the plant defense mechanisms involved in the Agrobacterium-Meloidogyne interaction, a reversetranscription quantitative polymerase chain reaction (RT-qPCR) analysis of JA/ET-regulated (ACO1, ACS6, COI1, ERF5, JA3, and $S l W R K Y 11)$ and SA-regulated (PR1 and NIM1) tomato genes was conducted.

\section{MATERIALS AND METHODS}

Single-pot experiments to evaluate pest-pathogen combined activity on the host plant, nematode reproduction, and crown gall incidence. Tomato (Solanum lycopersicum L.) hybrid 'Arawak' (Syngenta) seed were used in pot experiments (Table 1). Before planting, seed were surface sterilized in $70 \%$ ethanol for 15 min, soaked in $2.5 \% \mathrm{NaOCl}$ with a drop of Tween 20 for $30 \mathrm{~min}$, and washed in sterile water. Efficiency of surface sterilization was tested on King's B (KB) medium for 1 week where aliquots of seed were germinated. Dry seed were planted into a mixture of autoclaved sand $(0.25$ to $1.0 \mathrm{~mm})$ and hydroculture granules (1 to $4 \mathrm{~mm}$ ) at a $3: 1$ ( $(\mathrm{vol} / \mathrm{vol})$ ratio. After 2 weeks, seedlings were transplanted into pots with $600 \mathrm{~cm}^{3}$ of sterilized sand and watered daily with sterile nutrient solutions for hydroponic growth (General Hydroponics) at $\mathrm{pH} 5.5 \pm 0.2$. The plants were grown in a growth chamber at an average daily temperature of $23.3^{\circ} \mathrm{C}$ and $14-\mathrm{h}$ photoperiod. Four-week-old seedlings were used in pot experiments.

A population of $M$. ethiopica (Širca et al. 2004) from Slovenia (Table 1) was maintained on susceptible 'Saint Pierre' tomato plants in a greenhouse. Egg inoculum was obtained from the infested tomato roots (Hussey and Barker 1973) and cleansed following the modified protocol of McClure et al. (1973). Nematode eggs retrieved from the $32-\mu \mathrm{m}$ sieve and collected into 50-ml polycarbonate centrifuge tubes were centrifuged at $952 \times g$ for $5 \mathrm{~min}$. The pellets were resuspended in $45.4 \%$ (wt/vol) sucrose solution and centrifuged at $635 \times g$ for $1 \mathrm{~min}$. The supernatant containing eggs was poured over a $32-\mu \mathrm{m}$ sieve and rinsed with tap water. A clean suspension of eggs was collected from the sieve. Eggs were surface sterilized in $0.002 \% \mathrm{HgCl}_{2}$ for $4 \mathrm{~min}$ and rinsed three times in sterile water. Egg concentrations were estimated with a stereomicroscope.

Agrobacterium tumefaciens (Smith and Townsend 1907) Conn 1942 strains 06-424-7 and 50-1 from Slovenia were used (Table 1). The isolates were maintained at $-80^{\circ} \mathrm{C}$, revitalized on $\mathrm{KB}$ plates for 2 days at $27^{\circ} \mathrm{C}$, and subcultured. A loopfull of inoculum was transferred from a 1-day-old culture into $100 \mathrm{ml}$ of liquid $\mathrm{KB}$ medium and incubated at $27^{\circ} \mathrm{C}$ for 16 to $18 \mathrm{~h}$ on a laboratory shaker. The culture was pelleted at $1,000 \times g$ for $15 \mathrm{~min}$ and washed two times in sterile water. A bacterial inoculation suspension of approximately $10^{8} \mathrm{CFU} / \mathrm{ml}$ was prepared by adjusting the transmittance to $80 \%$. Transmittance was measured with a turbidimeter (BioLog). Pathogenicity of reisolated A. tumefaciens from experimental pots was assessed on tomato plants at the end of the experiment. The tomato stem was punctured three times using a sterile entomological needle dipped into 1-day-old culture colonies grown on $\mathrm{KB}$ medium at $27^{\circ} \mathrm{C}$. After 3 to 6 weeks, the plants were visually inspected for tumor formations.

Roots of 4-week-old tomato seedlings were inoculated with 2,000 M. ethiopica eggs and A. tumefaciens strain 06-424-7 at $10^{6} \mathrm{CFU} / \mathrm{g}$ of sand, or water (mock control). Before the experiment, the pathogenic strain 06-424-7 was tested for its capability to form tumors at $10^{6}$ $\mathrm{CFU} / \mathrm{g}$ of sand on the roots of tomato. Inoculations were performed with a syringe to inject the inoculation suspension directly into substrate through three holes positioned around the tomato plant. The experimental design and treatments are described in Table 2. The experiment was conducted twice; six and five replicates per treatment were used in the first and second pot experiments, respectively. We added an additional treatment (N2npB1) to the second experiment, where a pathogenic $A$. tumefaciens strain was replaced by a nonpathogenic one (50-1) (Tables 1 and 2). Both experiments ended 45 days postinoculation (dpi) according to an equation model for the nematode reproduction cycle at different temperatures (Strajnar et al. 2011). Yet another experiment was set up to evaluate the interaction after the second reproduction cycle of the M. ethiopica nematode (90 dpi) designed in four different treatments (Table 2). This experiment was conducted once with five replicates per treatment. In all three experiments, the pots were randomly arranged in the growth chamber and, once a week, randomly rearranged to provide fairly similar conditions to the plants.

Tomato plants were harvested 45 or 90 days after the onset of the experiments. Shoots were cut, their length measured, and fresh weight recorded. The shoots were dried at $65^{\circ} \mathrm{C}$ for $72 \mathrm{~h}$ and weighed. Roots were washed by soaking and rinsing with tap water. Tumors were counted and excised. Fresh root weight was assessed by cutting the root into $1-\mathrm{cm}$ strips that were thoroughly mixed in water, passed through filter discs $\left(40 \mathrm{~g} / \mathrm{m}^{2}\right.$; Munketell) to remove gravitational water, and then weighed. A root subsample of $0.5 \mathrm{~g}$ was used for gall and egg sac enumeration by staining the roots in

TABLE 1. Organisms used in this study

\begin{tabular}{|c|c|c|c|}
\hline Organism & Cultivar, strain & Characteristics & Source \\
\hline Solanum lycopersicum L. & Arawak F1 & Tomato hybrid, susceptible to $\mathrm{RKN}^{\mathrm{y}}$ & Syngenta \\
\hline Meloidogyne ethiopica & Slovenian population & Root-knot nematode & Laboratory collection \\
\hline \multirow[t]{4}{*}{ Agrobacterium tumefaciens } & $06-424-7$ & $\begin{array}{l}\text { Pathogenic, isolated from rose tumor, } \\
\text { group G1 }\end{array}$ & Laboratory collection \\
\hline & $50-1$ & Nonpathogenic soil isolate, group $\mathrm{G} 1^{\mathrm{z}}$ & Laboratory collection (Lamovšek et al. 2014) \\
\hline & C58 & Pathogenic, group $\mathrm{G} 8^{\mathrm{z}}$ & INRA \\
\hline & C58C1 & Nonpathogenic, cured from pTiC58 & INRA \\
\hline Escherichia coli & JM109 & Nonpathogenic & Promega Corp. \\
\hline
\end{tabular}

y $\mathrm{RKN}=$ root-knot nematodes.

z Genomic species of A. tumefaciens species complex (Costechareyre et al. 2010). 
Phloxine B (15 mg/liter) for $20 \mathrm{~min}$. The total number of eggs was estimated according to Hussey and Barker (1973). The roots were chopped in a kitchen blender in $1 \% \mathrm{NaOCl}$ for 3 to $4 \mathrm{~min}$. The macerated roots were poured through three sieves, each carefully washed, to gather the eggs on a $32-\mu \mathrm{m}$ sieve, then collected in a 50-ml centrifuge tube. Appropriate dilutions were used to determine the egg concentration by counting eggs under a binocular stereomicroscope. The $M$. ethiopica reproduction was evaluated by calculating the reproduction factor ( $\mathrm{Rf})$, represented as ratio between final nematode egg number on host roots and initial inoculated number of eggs.

In treatments with bacteria, a sample of sandy substrate was taken to assess the bacterial concentration in each pot after the experiment. Sand (10 g) was mixed with $90 \mathrm{ml}$ of sterile water and shaken for $30 \mathrm{~min}$ at $300 \mathrm{rpm}$. Four 10-fold serial dilutions were prepared from the sand suspension and streaked onto selective medium 1A (Schaad et al. 2001) supplemented with tellurite (Mougel et al. 2001) in three replicates per sample. The plates were incubated at $27^{\circ} \mathrm{C}$ for 3 to 4 days. According to visual inspection, the number of CFU per gram of sand was determined (Mougel et al. 2001). Data from two experiments were pooled.

Split-root experiment to evaluate systemic response of tomato roots to agrobacteria and $M$. ethiopica reproduction. For evaluating the systemic plant response, a split-root technique was used. One week after seed germination in sterile sand, seedlings were uprooted and the lateral root growth stimulated by cutting off the root tip with a sterile blade. The seedlings were repotted in sterilized sand substrate and maintained on a 14-h light cycle at the average daily temperature of $23.3^{\circ} \mathrm{C}$. After an additional 2 weeks of growth, the seedlings were uprooted, the root system was divided into two parts, each part planted into $250 \mathrm{~g}$ of sterile sandy substrate in two separate pots that had been glued together, and a plastic stick was placed between the pots for the support of the tomato stem. After two additional weeks, the roots of one pot were inoculated with 1,000 M. ethiopica eggs and the roots in the other pot with A. tumefaciens at $10^{6} \mathrm{CFU} / \mathrm{g}$ of sand. The split-root experiment was designed in six different treatments with four replicates (Table 2). In addition to $A$. tumefaciens strain 06-424-7, we included treatments with heat-killed strain 06-424-7 and living nonpathogenic bacteria Escherichia coli JM109 (Table 1). The inoculations were performed with a syringe injecting the inoculation suspension directly into the sand close to the roots. Experimental design and treatments are explained in Table 2.

$M$. ethiopica juvenile penetration into tomato roots. To assess the effect of $A$. tumefaciens on $M$. ethiopica nematode penetration, an experiment using the split-root tomato plants was designed involving the treatment with 1,000 M. ethiopica eggs and pathogenic A. tumefaciens strain 06-424-7 at $10^{6} \mathrm{CFU} / \mathrm{g}$ of sand. The experimental design included three treatments in six replicates: (i) nematodes but no bacteria to roots of both pots at 0 days, (ii) nematodes to roots in one pot at 0 days and bacteria and nematodes to roots (NB) in the other pot at 0 days, and (iii) inoculation of strain 06-424-7 into the plant stem for tumor induction at 0 days and nematodes into both pots at 14 days (Table 3 ). To count the juveniles that entered the roots, plants from each treatment were uprooted and roots were rinsed and stained with acid fuchsin (Byrd et al. 1983) after 8 and 12 dpi.

Statistical analysis of pot experiment data. Statistical analysis was performed with R Software (v. 3.0.0.) and the Rcmdr package (v. 1.9-6) (R Development core team, www.r-project.org/). The homogeneity of variances was confirmed (Levene's test) prior to analysis of variance $(P<0.05)$. The Tukey's honestly significant

TABLE 2. Treatment description of pot trials for evaluating interactions of Agrobacterium tumefaciens, Meloidogyne ethiopica, and tomato in single-pot and split-root (two-pot) experiments

\begin{tabular}{|c|c|c|c|c|c|c|c|}
\hline \multirow[b]{2}{*}{ Treatment } & \multirow[b]{2}{*}{ Root part } & \multicolumn{2}{|r|}{ Inoculation } & \multicolumn{2}{|c|}{ Replicates $(n)$} & \multirow[b]{2}{*}{ End $^{r}$} & \multirow[b]{2}{*}{ Note } \\
\hline & & Time & Inoculum & Date 1 & Date 2 & & \\
\hline \multicolumn{8}{|l|}{ Single pot } \\
\hline \multirow[t]{2}{*}{ Control } & Whole & 0 & Water (mock) & 6 & 5 & 45 & Data pooled \\
\hline & Whole & & Water (mock) & 5 & & 90 & \\
\hline \multirow[t]{2}{*}{$\mathrm{N}^{\mathrm{s}}$} & Whole & 0 & M. ethiopica & 6 & 5 & 45 & Data pooled \\
\hline & Whole & & M. ethiopica & 5 & & 90 & \\
\hline $\mathrm{B}^{\mathrm{t}}$ & Whole & 0 & A. tumefaciens strain 06-424-7 & 6 & 5 & 45 & Data pooled \\
\hline \multirow[t]{2}{*}{$\mathrm{NB}^{\mathrm{u}}$} & Whole & 0 & M. ethiopica & 6 & 5 & 45 & Data pooled \\
\hline & Whole & 0 & A. tumefaciens strain 06-424-7 & & & & \\
\hline \multirow[t]{2}{*}{$\mathrm{N}_{1 B} 2^{\mathrm{v}}$} & Whole & 0 & M. ethiopica & 6 & 5 & 45 & Data pooled \\
\hline & Whole & 8 & A. tumefaciens strain 06-424-7 & 5 & & 90 & \\
\hline \multirow[t]{2}{*}{$\mathrm{N} 2 \mathrm{~B} 1^{\mathrm{w}}$} & Whole & 0 & A. tumefaciens strain 06-424-7 & 6 & 5 & 45 & Data pooled \\
\hline & Whole & 2 & M. ethiopica & 5 & & 90 & \\
\hline \multirow[t]{2}{*}{$\mathrm{N} 2 \mathrm{npB} 1^{\mathrm{x}}$} & Whole & 0 & A. tumefaciens strain 50-1 & 5 & 5 & 45 & Data pooled \\
\hline & Whole & 2 & M. ethiopica & & 5 & 45 & \\
\hline \multicolumn{8}{|l|}{ Split root } \\
\hline \multirow[t]{2}{*}{$\mathrm{N}^{\mathrm{s}}$} & A & 0 & M. ethiopica & 4 & $\ldots$ & 45 & $\ldots$ \\
\hline & B & & Water & & $\ldots$ & & $\ldots$ \\
\hline \multirow[t]{2}{*}{$\mathrm{NB}^{\mathrm{u}}$} & A & 0 & M. ethiopica & 4 & $\ldots$ & 45 & $\ldots$ \\
\hline & $\mathrm{B}$ & 0 & A. tumefaciens strain 06-424-7 & 4 & $\ldots$ & 45 & $\ldots$ \\
\hline \multirow[t]{2}{*}{$\mathrm{N} 1 \mathrm{~B} 2^{\mathrm{v}}$} & A & 0 & M. ethiopica & 4 & $\ldots$ & 45 & $\ldots$ \\
\hline & $\mathrm{B}$ & 8 & A. tumefaciens strain 06-424-7 & 4 & $\ldots$ & 45 & $\ldots$ \\
\hline \multirow[t]{2}{*}{$\mathrm{N} 2 \mathrm{~B} 1^{\mathrm{w}}$} & A & 0 & A. tumefaciens strain 06-424-7 & 4 & $\ldots$ & 45 & $\ldots$ \\
\hline & $\mathrm{B}$ & 2 & M. ethiopica & 4 & $\ldots$ & 45 & $\ldots$ \\
\hline \multirow[t]{2}{*}{$\mathrm{N} 2 \mathrm{hkB} 1^{\mathrm{y}}$} & A & 0 & Heat-killed A. tumefaciens strain 06-424-7 & 4 & $\ldots$ & 45 & $\ldots$ \\
\hline & B & 2 & M. ethiopica & 4 & $\ldots$ & 45 & $\ldots$ \\
\hline \multirow[t]{2}{*}{$\mathrm{N} 2 \mathrm{Ec} 1^{\mathrm{z}}$} & A & 0 & Escherichia coli JM109 & 4 & $\ldots$ & 45 & $\ldots$ \\
\hline & $\mathrm{B}$ & 2 & M. ethiopica & 4 & $\ldots$ & 45 & $\ldots$ \\
\hline
\end{tabular}

$\mathrm{r}$ Trial end (days).

s Treatment with $M$. ethiopica (2,000 eggs/pot; 1,000 eggs/pot in split root).

t Treatment with A. tumefaciens water suspension $\left(10^{6} \mathrm{CFU} / \mathrm{g}\right.$ of soil).

u Simultaneous treatment with M. ethiopica (2,000 eggs/pot; 1,000 eggs in split root) and A. tumefaciens (106 CFU/g of soil).

v Treatment with $M$. ethiopica (2,000 eggs/pot; 1,000 eggs in split root) 8 days before A. tumefaciens (106 CFU/g of soil).

${ }^{\text {w }}$ Treatment with A. tumefaciens ( $10^{6} \mathrm{CFU} / \mathrm{g}$ of soil) 2 days before $M$. ethiopica (2,000 eggs/pot; 1,000 eggs in split root).

${ }^{\mathrm{x}}$ Treatment with nonpathogenic strain of A. tumefaciens $\left(10^{6} \mathrm{CFU} / \mathrm{g}\right.$ of soil) 2 days before M. ethiopica (2,000 eggs/pot).

y Treatment with heat-killed strain of A. tumefaciens ( $10^{6} \mathrm{CFU} / \mathrm{g}$ of soil) 2 days before M. ethiopica (2,000 eggs/pot; 1,000 eggs in split root).

${ }^{\mathrm{z}}$ Treatment with a strain of Escherichia coli $\left(10^{6} \mathrm{CFU} / \mathrm{g}\right.$ of soil) 2 days before M. ethiopica (2,000 eggs/pot; 1,000 eggs in split root). 
difference test was applied when significant differences between the treatments were observed. Data from single-pot experiments that ended after 45 days were pooled (Table 2). Where appropriate, the data were log-transformed to ensure normality of the variances.

Split-root experiment for evaluation of systemic plant response based on gene expression of selected target tomato genes. RT-qPCR based on SYBR Green I as a reporter molecule was used to quantify gene expression of 10 selected target genes. We used split-root tomato pots where only one pot was inoculated; the other pot was used for root sampling. Two A. tumefaciens strains were used in this experiment: a pathogenic strain C58 and commonly used nonpathogenic strain $\mathrm{C} 58 \mathrm{C} 1$ that is cured of its pTiC58 plasmid (Table 1). The experimental design was similar to the 45-dpi experiment (Table 4) and included six treatments with four replicates per time point (Table 4): (i) Control (water in one pot, 0 days); (ii) 1,000 M. ethiopica eggs in one pot, 0 days; (iii) C58 (A. tumefaciens strain C58 at $10^{6} \mathrm{CFU} / \mathrm{g}$ of sand in one pot, 0 days); (iv) $\mathrm{C} 58 \mathrm{C} 1$ (A. tumefaciens strain $\mathrm{C} 58 \mathrm{C} 1$ at $10^{6} \mathrm{CFU} / \mathrm{g}$ of sand in one pot, 0 days), (v) N2B1 (in the same pot, A. tumefaciens strain C58 was inoculated at 0 days and $M$. ethiopica eggs 2 days later); and (vi) N1B2 (in the same pot, $M$. ethiopica eggs were inoculated at 0 days and $A$. tumefaciens strain C58 8 days later). Roots were sampled at 0,4 , and $12 \mathrm{dpi}$. A noninoculated part of the root was rinsed gently in tap water to remove the sand and subsequently crushed in liquid nitrogen. Meanwhile, the inoculated roots and the stem remained attached to the plant. The first sampling at 0 dpi was performed within $15 \mathrm{~min}$ after the first inoculations. Pulverized root samples were stored at $-80^{\circ} \mathrm{C}$ until they were processed. According to the manufacturer's instructions for the RNeasy Plant Mini Kit (Qiagen), we used $100 \mathrm{mg}$ of root tissue to extract total RNA. The quality and quantity of the extracted RNA was assessed on the Agilent 2100 Bioanalyzer (Agilent Technologies) with Agilent RNA 6000 Nano Chips, according to the manufacturer's instructions. All root samples had RNA integrity numbers above 9.0. Genomic DNA was degraded using the TURBO DNase free kit (Life Technologies) on samples containing $2 \mu \mathrm{g}$ of RNA in a reaction volume of $25 \mu \mathrm{l}$. The absence of genomic DNA was assessed with the Eukaryotic 18S ribosomal RNA endogenous control (VIC/MGB probe, primer limited; Life Technologies) and RNA was reverse transcribed to complement DNA (cDNA) with the high-capacity cDNA RT kit, according to the manufacturer's instructions (Life Technologies). Synthesis was completed in triplicate, with $25-\mu \mathrm{l}$ reactions (500 ng of total RNA) pooled into one sample and stored at $-20^{\circ} \mathrm{C}$.

Genes involved in the JA/ET or SA defense signalization were selected as targets (Bhattarai et al. 2010; Journot-Catalino et al. 2006; Mantelin et al. 2013; Pozo et al. 2008; Son et al. 2012; Ward et al. 1991; Weyman et al. 2006; Wu et al. 2012; Xie et al. 1998) and amplified with designed primers (Table 5). Previous studies were used for selecting four reference genes (Table 6) and their amplification primers (Table 5) (Fernández et al. 2014; Fowler et al. 2009; Løvdal and Lillo 2009) for data normalization according to gene stability

TABLE 3. Number of Meloidogyne ethiopica nematode juveniles (RKN) that penetrated into the roots of tomato 8 and 12 days after joined inoculations with nematodes and agrobacteria (Agrobacterium tumefaciens strain C58) in split-root experiment ${ }^{\mathrm{x}}$

\begin{tabular}{|c|c|c|c|c|c|c|c|}
\hline \multirow[b]{2}{*}{ Treatment $^{\mathrm{y}}$} & \multirow[b]{2}{*}{ Pot } & \multicolumn{2}{|c|}{ Inoculation } & \multicolumn{4}{|c|}{ Number of juveniles } \\
\hline & & Time & Inoculum & $n$ & 8 days & $n$ & 12 days \\
\hline \multirow[t]{2}{*}{$\mathrm{N}$} & A & 0 & RKN & 3 & $\ldots$ & 3 & $\ldots$ \\
\hline & B & 0 & RKN & 3 & $20.0 \pm 3.14^{z}$ & 3 & $38.7 \pm 4.13^{z}$ \\
\hline N_NB & B & 0 & $\mathrm{RKN}+\mathrm{C} 58$ & 6 & $18.2 \pm 6.01$ & 6 & $33.3 \pm 3.68$ \\
\hline \multirow[t]{2}{*}{$\mathrm{T}$} & A & 0 & RKN & 0 & n.a. & 3 & $\ldots$ \\
\hline & B & 0 & RKN & 0 & n.a. & 3 & $34.0 \pm 6.52^{z}$ \\
\hline
\end{tabular}

TABLE 4. Treatment description of split-root pot experiment for evaluating systemic plant response to Agrobacterium tumefaciens and Meloidogyne ethiopica at the level of target gene expression in roots of tomato

\begin{tabular}{|c|c|c|c|c|c|}
\hline \multirow[b]{2}{*}{ Treatment } & \multirow[b]{2}{*}{ Pot } & \multicolumn{2}{|c|}{ Inoculation } & \multirow[b]{2}{*}{ Replicates (n) } & \multirow[b]{2}{*}{ Sampling (dpi) } \\
\hline & & Time & Inoculum & & \\
\hline \multirow[t]{2}{*}{ Control } & A & 0 & Sterile water & 4 & \\
\hline & B & 0 & Sterile water & 4 & $0,4,12$ \\
\hline $\mathrm{N}^{\mathrm{v}}$ & B & 0 & Sterile water & 4 & $0,4,12$ \\
\hline \multirow[t]{2}{*}{ C58 } & A & 0 & A. tumefaciens strain C58 & 4 & \\
\hline & B & 0 & Sterile water & 4 & $0,4,12$ \\
\hline \multirow[t]{3}{*}{$\mathrm{N} 1 \mathrm{~B} 2^{\mathrm{y}}$} & A & 0 & M. ethiopica & 4 & \\
\hline & A & 8 & A. tumefaciens strain C58 & 4 & \\
\hline & B & 8 & Sterile water & 4 & $0,4,12$ \\
\hline \multirow[t]{3}{*}{$\mathrm{N} 2 \mathrm{~B} 1^{\mathrm{z}}$} & A & 0 & A. tumefaciens strain C58 & 4 & \\
\hline & A & 2 & M. ethiopica & 4 & \\
\hline & B & 2 & Sterile water & 4 & $0,4,12$ \\
\hline
\end{tabular}

u Sampling of roots in pot B at 0,4 , and 12 days postinoculation (dpi).

v Treatment with M. ethiopica (1,000 eggs/pot A).

w Treatment with A. tumefaciens strain C58 water suspension $\left(10^{6} \mathrm{CFU} / \mathrm{g}\right.$ of soil in pot A).

x Treatment with A. tumefaciens strain C58C1 (without plasmid Ti) $\left(10^{6} \mathrm{CFU} / \mathrm{g}\right.$ of soil in pot A).

${ }^{y}$ Treatment with $M$. ethiopica (1,000 eggs/pot A) 8 days before A. tumefaciens strain C58 $\left(10^{6} \mathrm{CFU} / \mathrm{g}\right.$ of soil in pot A).

z Treatment with A. tumefaciens strain C58 $\left(10^{6} \mathrm{CFU} / \mathrm{g}\right.$ of soil in pot A) 2 days before M. ethiopica (1,000 eggs/pot A). 
expression analysis (Hellemans et al. 2007; Vandesompele et al. 2002). The target gene sequences were downloaded from the ENA database (EMBL-EBI) and primer sequences were constructed with the Primer3 tool (Untergasser et al. 2012). Primer pairs with optimal annealing temperature of $60^{\circ} \mathrm{C}$ and a length of 20 to $22 \mathrm{bp}$ were selected. Primer specificity was assessed with the Primer-BLAST algorithm (National Center for Biotechnology Information) (Altschul et al. 1990) on all available tomato sequences.

The qPCR was performed on a 7500 Fast Real-Time PCR System (Life Technologies) under universal conditions $\left(95^{\circ} \mathrm{C}\right.$ for $10 \mathrm{~min}$ followed by 40 cycles of $95^{\circ} \mathrm{C}$ for $15 \mathrm{~s}$ and $60^{\circ} \mathrm{C}$ for $1 \mathrm{~min}$ ) and a final dissociation step. Each cDNA sample was run in duplicate. The specificity of the reaction was assessed according to the shape of retrieved melting curves and the shape of the nontemplate control, and additionally verified on $2 \%$ agarose gel. The amplification efficiencies for each primer pair were calculated from standard curves on dilutions of a mixed cDNA sample in triplicate and analyzed with the 7500 Software v.2.0.6 (Life Technologies). The interrun variation was controlled by adding three interplate calibration samples to each plate in duplicate. The stability of reference gene expressions was evaluated according to the method of Vandesompele et al. (2002) as implemented in the SLqPCR R package (Kohl 2007).

Quantitative cycle values were tested for differential expression using the Bioconductor package unified WMWqPCR for analysis of RT-qPCR data in R that also incorporates normalization (De Neve et al. 2013). Gene expression was interpreted from values of log of odds ratio, giving the estimate of the probability that the target gene from the independent treatment is upregulated in treatment 1 but not in treatment 2 .

\section{RESULTS}

Tomato growth in the presence of pathogenic agrobacteria and RKN on roots. Single-pot experiments were conducted to evaluate the effect of combined infection (A. tumefaciens and
M. ethiopica) on plant vitality (Table 2). A. tumefaciens strain 06424-7 and M. ethiopica nematodes induced tumors and galls but did not affect plant vitality during the experiment (45 or 90 dpi) because of the low concentration of applied inocula. No statistically significant change in tomato root weight or change in fresh and dry shoot weight was recorded $45 \mathrm{dpi}$, although the treated plants were $3.5 \mathrm{~cm}$ shorter, on average, than control plants $(P<0.001)$ (Table 7). After $90 \mathrm{dpi}$, treated plants appeared healthy, although the water content of the shoots was reduced $(P<0.05)$. Infestations with $M$. ethiopica eggs alone caused the greatest reduction in fresh shoot weight (average $=9.2 \mathrm{~g}$ ) and a reduced dry shoot weight of $1.8 \mathrm{~g}$. Due to galls, the $M$. ethiopica-infested roots were heavier than noninfested roots at 90 dpi (Table 7).

M. ethiopica reproduction in the presence of agrobacteria. Uprooted tomato plants from single-pot experiments (Table 2) were used for determination of $M$. ethiopica $\mathrm{Rf}$. The Rf was lowest in treatment N2B1, where A. tumefaciens strain 06-424-7 was added 2 days prior to $M$. ethiopica nematode eggs (Table 7). In treatment $\mathrm{N} 2 \mathrm{~B} 1$, the final egg count was $59 \%$ lower than in control treatments. A statistically similar reduction $(68 \%)$ was also received with nonpathogenic strain 50-1 (Table 7). Lower nematode reproduction also was determined in treatment N2B1 at 90 dpi. The highest $M$. ethiopica reproduction was observed in treatment N1B2 after 90 days $(P=0.012)$ (Table 7$)$.

TABLE 6. Stability of reference genes expression ${ }^{\mathrm{z}}$

\begin{tabular}{lcc}
\hline Gene & CV $(\%)$ & $M$ value \\
\hline BTUB & 29.21 & 0.485 \\
UBI & 10.39 & 0.286 \\
EF1L & 15.44 & 0.362 \\
RPL2 & 10.15 & 0.341 \\
Average & 11.63 & 0.368 \\
\hline
\end{tabular}

${ }_{\mathrm{z}} \mathrm{CV}=$ coefficient of variation (\%) and $M=$ gene expression stability $(M \leq 1.5)$.

TABLE 5. List of target and reference genes with the primer pair sequences used in this studyz

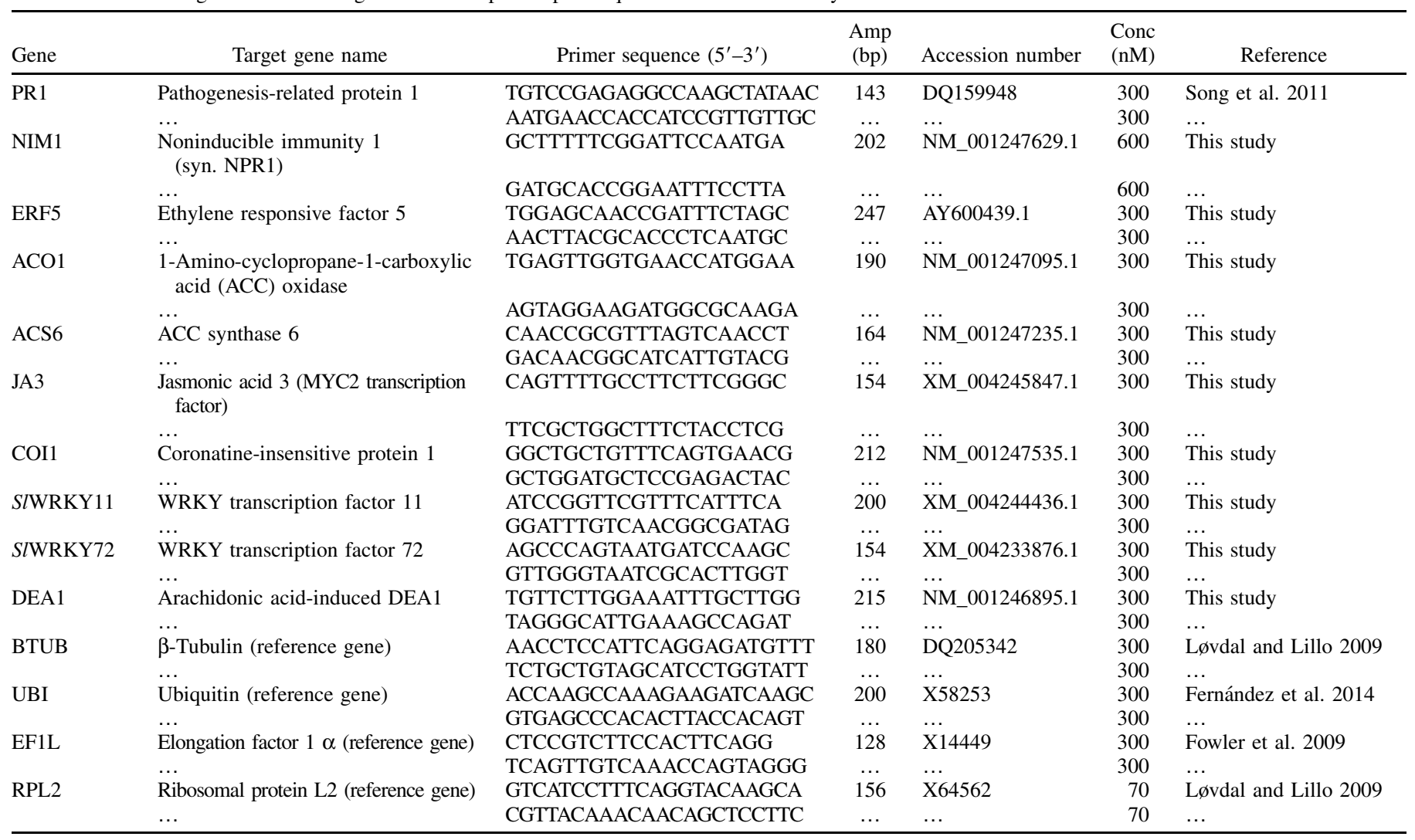

${ }_{\mathrm{z}}$ Amp $=$ amplicon length and Conc $=$ primer concentration. 
Reduced final M. ethiopica egg number in N2B1 directly corresponds to low number of galls and egg masses. The lowest number of galls and egg masses was observed in treatments N2B1 and N2npB1 at 45 dpi (Table 7). Compared with the control treatment, the roots in N2B1 (N2npB1) had 55\% (65\%) less galls. Only one egg mass, on average, extruded from the surface of each gall. After 90 days. the galls were larger and hosted more than one female nematode, with egg masses hidden inside the single gall.

Agrobacteria indirectly affecting $\mathrm{RKN}$ reproduction. A split-root pot experiment was set up to evaluate the influence of systemic plant response on the observed suppression in treatment N2B1 (Table 2). The reproduction of the nematode was reduced if agrobacteria were present on the other, physically separated root segments in treatment N2B1 (Table 8). The reduction in numbers of galls and egg masses was even higher when heat killed A. tumefaciens strain 06-424-7 (N2hkB1) or the nonpathogenic E. coli strain (N2Ec1) were added. On the other hand, in treatment N1B2, the nematodes produced $290 \%$ more galls than in treatment N2B1 and $62 \%$ more galls than in the control treatment (Table 8).

Penetration of $M$. ethiopica juveniles into the roots was not affected by agrobacteria. Split-root experiment described in Table 3 was set up to evaluate the penetration of M. ethiopica juveniles into roots of tomato when A. tumefaciens is present. The bacteria A. tumefaciens did not influence the penetration of M. ethiopica juveniles into the tomato roots. Neither direct physical presence nor indirect presence on other root segments affected the rate of $M$. ethiopica penetration into the roots at 8 and $12 \mathrm{dpi}$ (Table 3). Furthermore, the presence of tumors on the plant stem did not affect the penetration of $M$. ethiopica nematodes into the roots.

Tumor development by agrobacteria was reduced in the presence of $M$. ethiopica. In single-pot experiments, in the treatment with pathogenic bacteria A. tumefaciens (treatment B), tumors did not develop on 3 of 11 plants. The other eight test plants from treatment B developed one or more tumors on the roots; however, no tumor was formed at the crown stem (Table 9). None of the plants from the control treatment that was treated with water developed tumors. The presence of M. ethiopica reduced tumor incidence by $18 \%$ when A. tumefaciens was inoculated before the M. ethiopica eggs (NB and N2B1). Tumor development was completely prevented in N1B2 when $M$. ethiopica juveniles invaded the roots and began forming feeding sites prior to root infection with bacteria. The density of A. tumefaciens in the growth substrate of different treatments did not significantly decrease at 45 dpi (Table 9).

Differential expression of tomato JA/ET pathway target genes. A split-root experiment was set-up to sample only noninoculated root segments (Table 4). All four reference genes had a steady expression in all treated and control root samples (Table 6). The majority of target genes did not show differences in gene expression (Table 10). According to the results, the most significant downregulation of selected target genes was induced by pathogenic A. tumefaciens strain C58 alone. Immediate systemic response of tomato to $\mathrm{C} 58$ consisted of a downregulation of ET synthesis gene 1-amino-cyclopropane-1-carboxylic acid (ACC) synthase (ACS) 6 (0 dpi). ACS enzymes are part of the ET biosynthesis pathway, together with ACC oxidases $(A C O)$ that catalyze the final step in ET synthesis. Downregulation of gene $A C O 1$ was detected at 12 dpi, together with the positive detection of SA-inducible pathogenesis-related (PR) protein gene $P R 1$ (Fig. 1A). A similar pattern in gene expression was noted in C58- and C58C1-treated plants in the early stages of pathogenesis. However, at $12 \mathrm{dpi}$, the pathogenic C58 induced stronger downregulation of $P R 1$ and $A C O 1$ than $\mathrm{C} 58 \mathrm{C} 1$, indicating

TABLE 8. Evaluation of Meloidogyne ethiopica reproduction in the split-root pot experiment $(45 \mathrm{dpi})^{\mathrm{y}}$

\begin{tabular}{lcc}
\hline Treatment ${ }^{z}$ & $\begin{array}{c}\text { Number of } \\
\text { galls/g of root }\end{array}$ & $\begin{array}{c}\text { Number of egg } \\
\text { masses/g of root }\end{array}$ \\
\hline $\mathrm{N}$ & $72.0 \pm 6.70 \mathrm{~b}$ & $41.9 \pm 8.21 \mathrm{bc}$ \\
$\mathrm{NB}$ & $66.5 \pm 20.56 \mathrm{~b}$ & $30.8 \pm 7.51 \mathrm{ab}$ \\
$\mathrm{N} 1 \mathrm{~B} 2$ & $116.4 \pm 9.98 \mathrm{c}$ & $66.3 \pm 14.76 \mathrm{c}$ \\
$\mathrm{N} 2 \mathrm{~B} 1$ & $29.9 \pm 6.04 \mathrm{ab}$ & $13.9 \pm 6.51 \mathrm{ab}$ \\
$\mathrm{N} 2 \mathrm{Ec} 1$ & $16.2 \pm 5.18 \mathrm{a}$ & $8.3 \pm 3.57 \mathrm{a}$ \\
N2hkB1 & $19.8 \pm 2.97 \mathrm{a}$ & $5.5 \pm 1.38 \mathrm{a}$ \\
$P$ (treatment) & $<0.001$ & $<0.001$ \\
\hline
\end{tabular}

y Data are represented as mean \pm standard error $(n=4)$. Within each column, values followed by different letters are significantly different $(P \leq 0.05)$ according to one-way analysis of variance and Tukey's honestly significant difference test (a to c).

z Treatment designations: $\mathrm{N}=$ infested with $M$. ethiopica eggs, $\mathrm{NB}=$ simultaneous inoculation with $M$. ethiopica and A. tumefaciens, N1B2 = A. tumefaciens inoculated 8 days after $M$. ethiopica, N2B1 = M. ethiopica inoculated 2 days after $A$. tumefaciens, N2Ec1 = M. ethiopica inoculated 2 days after Escherichia coli, and N2hkB1 = M. ethiopica inoculated 2 days after heat-killed pathogenic A. tumefaciens.

TABLE 7. Growth parameters of tomato plants and Meloidogyne ethiopica nematode reproduction parameters in pot experiments for evaluation of the Agrobacterium-Meloidogyne interaction on host plant vitality and nematode reproduction ${ }^{\mathrm{w}}$

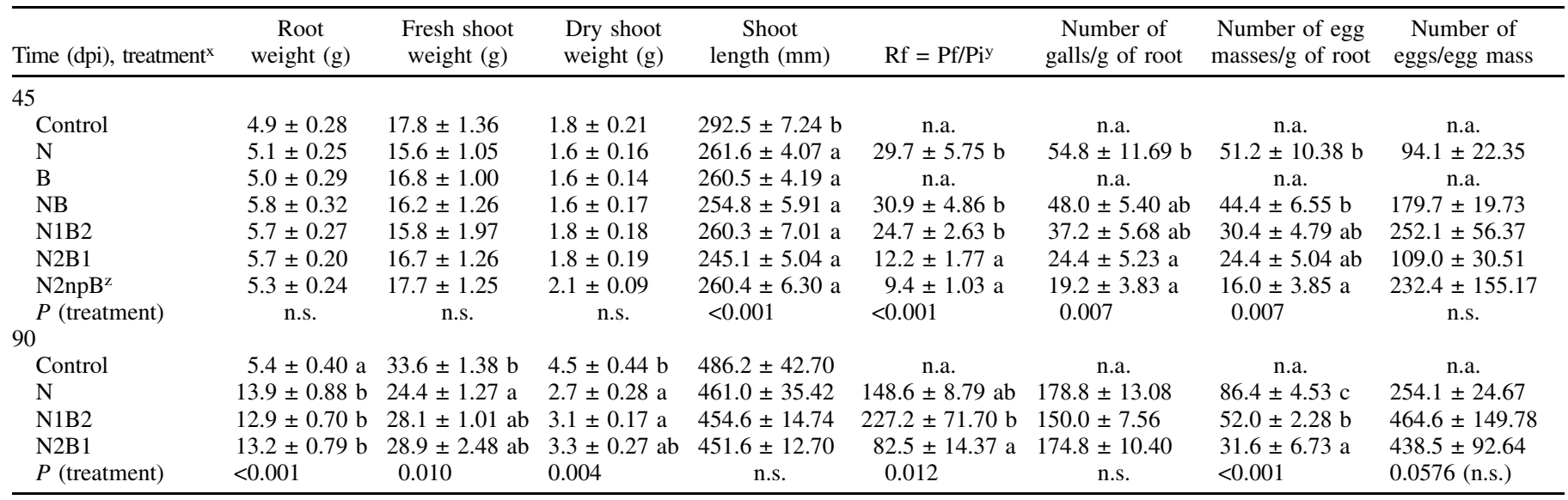

${ }^{\mathrm{w}}$ Data are represented as mean \pm standard error $(n=11$ for calculations after $45 \mathrm{dpi}$ and $n=5$ after $90 \mathrm{dpi})$. Values followed by lowercase letters are significantly different $(P \leq 0.05)$ according to one-way analysis of variance and Tukey's honestly significant difference test; n.s. $=$ not significant and n.a. $=$ not available.

x Treatment designations: Control $=$ uninfected, $\mathrm{N}=$ infested with $M$. ethiopica eggs, $\mathrm{B}=$ inoculated with pathogenic strain $A$. tumefaciens, $\mathrm{NB}=$ simultaneous inoculation with $M$. ethiopica and A. tumefaciens, N1B2 $=$ A. tumefaciens inoculated 8 days after $M$. ethiopica, N2B1 = M. ethiopica inoculated 2 days after A. tumefaciens, and $\mathrm{N} 2 \mathrm{npB} 1=$ M. ethiopica inoculated 2 days after nonpathogenic A. tumefaciens.

${ }^{y}$ Reproduction factor $(\mathrm{Rf})$ of $M$. ethiopica. $\mathrm{Pf}=$ total number of $M$. ethiopica eggs per root system and $\mathrm{Pi}=$ initial number of eggs $(2,000$ per treatment $)$.

$\mathrm{z}$ The N2npB1 treatment was conducted once $(n=5)$. 
the involvement of pTi genes in the suppression of plant defenses (Fig. 1A).

The gene for $P R 1$ that is known to be SA-induced was upregulated in N2B1 at 12 dpi where strain C58 was used (Table 10), even though the same gene was downregulated by $\mathrm{C} 58$ in a similar experiment in the absence of $M$. ethiopica (Fig. 1A). No $P R 1$ differential expression was detected in N1B2. However, the downregulation of ACS6 in N1B2 at 12 dpi could be attributed to the action of C58 (Fig. 1A).

To determine the contribution of M. ethiopica to C58-infected tomato roots on overall target gene expression in N2B1, we compared treatments N2B1 and C58 (Table 10). Two days after the $M$. ethiopica inoculation in $\mathrm{N} 2 \mathrm{~B} 1$, the general immunity gene SlWRKY72 showed significantly higher systemic expression than in C58 at the same sampling time (4 dpi) (Fig. 1B). It should be noted that the M. ethiopica nematodes and strain C58 alone downregulated SlWRKY72 at 4 dpi (Fig. 1B). Later, at $12 \mathrm{dpi}$, the expression of all target genes in $\mathrm{N} 2 \mathrm{~B} 1$ was comparable with expression in C58 $(P=0.014)$.

Different batches of $M$. ethiopica eggs were used in pot and splitroot experiments for the N2B1 treatment. Similar percentages of

TABLE 9. Tumor development on tomato roots in treatments with joined inoculation of Agrobacterium tumefaciens and Meloidogyne ethiopica nematodes $(45 \mathrm{dpi})^{\mathrm{x}}$

\begin{tabular}{lccc}
\hline Treatment $^{\mathrm{y}}$ & $\begin{array}{c}\text { Plants with } \\
\text { root tumors }(\%)\end{array}$ & $\begin{array}{c}\text { Tumor } \\
\text { weight }(\mathrm{mg})\end{array}$ & $\begin{array}{c}\text { Conc } \\
(\log C F U)^{\mathrm{z}}\end{array}$ \\
\hline $\mathrm{B}$ & $72.7(8 / 11)$ & $60 \pm 19.7$ & $5.8 \pm 0.08$ \\
NB & $54.5(6 / 11)$ & $130 \pm 40.4$ & $5.5 \pm 0.09$ \\
N1B2 & $0(0 / 11)$ & 0 & $5.6 \pm 0.10$ \\
N2B1 & $54.5(6 / 11)$ & $103 \pm 49.2$ & $5.5 \pm 0.11$ \\
\hline
\end{tabular}

${ }^{\mathrm{x}}$ Average tumor weight is presented as mean \pm standard deviation; logCFU values are presented as mean \pm standard error $(n=11)$. The experiment was conducted twice, in six and five replicates; data were pooled.

y Treatment designations: $\mathrm{B}=$ pathogenic A. tumefaciens (06-424-7), NB = simultaneous inoculation with $M$. ethiopica and $A$. tumefaciens, N1B2 = A. tumefaciens inoculated 8 days after $M$. ethiopica, and $\mathrm{N} 2 \mathrm{~B} 1=M$. ethiopica inoculated 2 days after $A$. tumefaciens.

${ }^{\mathrm{z}}$ Concentration of A. tumefaciens.
M. ethiopica egg populations were observed in the three pot experiments, and conclusions drawn from the pot experiments are also supported by gene expression analysis. Therefore, we assume that using different egg batches had no significant effect on the results.

\section{DISCUSSION}

Opinions regarding the Agrobacterium-Meloidogyne pathosystem have not changed considerably over the last 50 years. Based on field observations and a few field and lab experiments, it was concluded that synergism best describes the AgrobacteriumMeloidogyne relationship on host plants (Dhanvantari et. al 1975; Rubio-Cabetas et al. 2001; Süle et al. 1995; Zutra and Orion 1982). Recently, a considerable number of rhizobacteria have been identified as biocontrol agents against different plant-pathogenic bacteria and RKN (Hallmann et al. 2009). Given the fact that the genus Agrobacterium is part of the rhizosphere microbial community, it would not be presumptuous to assume that, despite being pathogenic, A. tumefaciens might suppress RKN. This hypothesis was tested in pot experiments on the RKN-susceptible tomato hybrid Arawak F1 (Syngenta). We opted for low inoculum sizes of both the pathogenic A. tumefaciens strain and pest $M$. ethiopica but kept the bacterial concentration above the density required for tumor formations $\left(>10^{5}\right.$ $\mathrm{CFU} \mathrm{g}^{-1}$ ) (Li et al. 2015).

Agrobacteria and $M$. ethiopica nematodes did not severely affect tomato growth. All tomato plants infected with A. tumefaciens or infested with $M$. ethiopica were smaller and the level of water content in the shoots was significantly reduced after 90 days as a consequence of root galling that also was observed by Strajnar et al. (2012). However, the effect of agrobacteria on the plant growth indices was negligible. Our observations agree with results from Fakhouri et al. (1996), who adopted a similar experimental design using tomato, A. tumefaciens, and M. javanica.

Positive, negative, and systemic effects of agrobacteria on reproduction of $M$. ethiopica nematodes. The results from pot experiments suggest that antagonism and synergism could describe the A. tumefaciens-M. ethiopica pathosystem. Timing of

TABLE 10. Summary of target gene differential expression probabilities (LogOr) compared with probabilities of upregulation in other independent treatments ${ }^{y}$

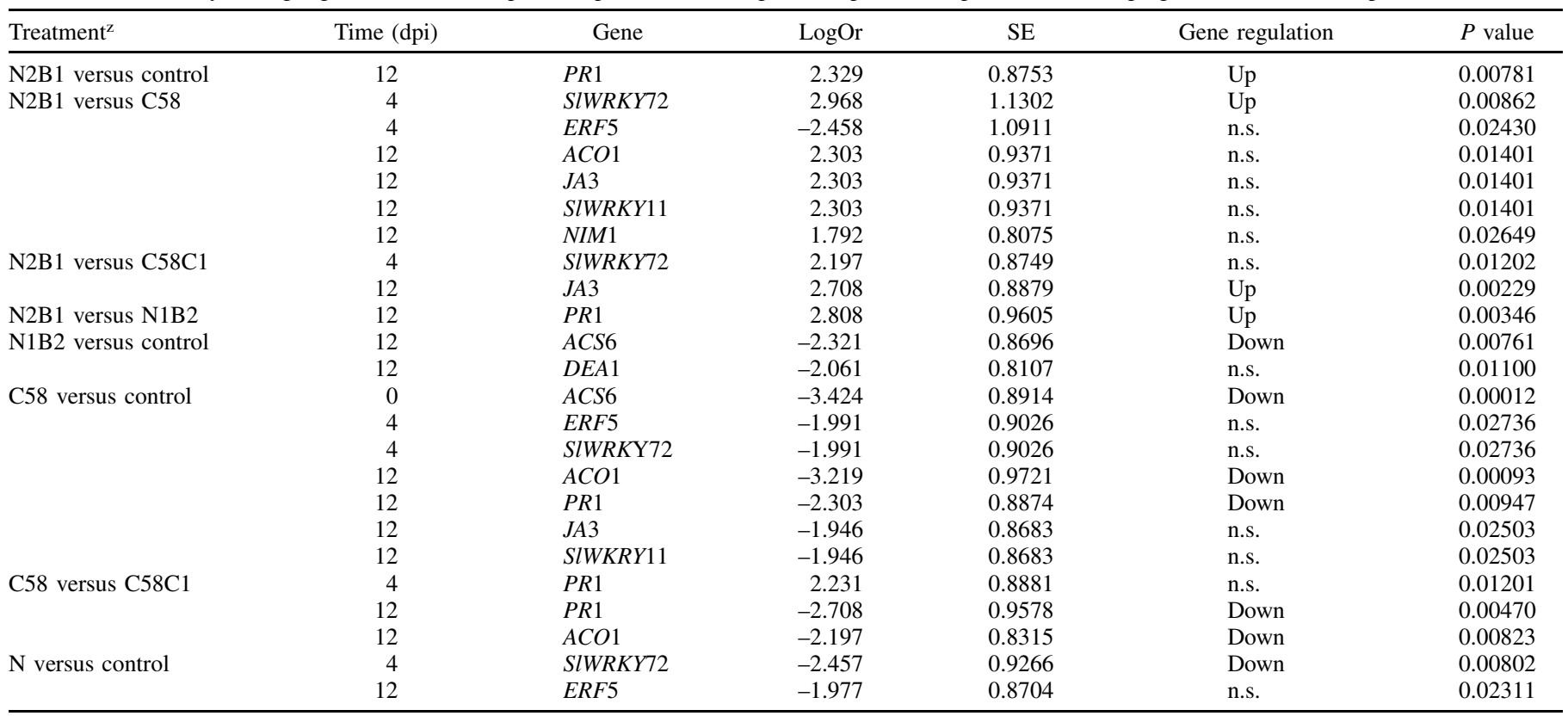

y Time $=$ days postinoculation (dpi), $\log \mathrm{Or}=\log$ of odds ratio (estimation of probability that selected gene is upregulated in the treatment), SE $=$ standard error, and n.s.- not significant. Statistically significant gene regulation at $P \leq 0.01$.

$\mathrm{z}$ Treatment designations: Control $=$ noninfected, N2B1 $=$ M. ethiopica inoculated 2 days after A. tumefaciens strain C58, C58 = inoculated with A. tumefaciens strain $\mathrm{C} 58, \mathrm{C} 58 \mathrm{C} 1=$ inoculated with nonpathogenic strain $\mathrm{C} 58 \mathrm{C} 1, \mathrm{~N} 1 \mathrm{~B} 2=$ A. tumefaciens strain $\mathrm{C} 58$ inoculated 8 days after $M$. ethiopica, and $\mathrm{N}=$ infested with M. ethiopica. 
the $M$. ethiopica introduction appears crucial. When $M$. ethiopica infested the roots prior to infection with bacteria, the egg counts were higher than in control treatments, but this positive effect was observed only after 90 days. This suggests that synergism between agrobacteria and $M$. ethiopica may apply only for the later stages of parasitism.

When $M$. ethiopica eggs were added on the A. tumefaciensinfected tomato roots, the egg counts were reduced after the first and second reproduction cycle, as were the numbers of galls and egg masses. However, the observed 59\% reduction in M. ethiopica egg counts after 45 days still resulted in a high nematode population. The next generation of $M$. ethiopica nematodes was still high and caused significant root galling after 90 days, albeit less than in control treatments. In spite of similar experimental design, Fakhouri et al. (1996) noted reduced $M$. javanica reproduction in treatments where agrobacteria and nematodes were added simultaneously to the roots of tomato. The difference in results could be ascribed to different RKN and bacterial species, subtle variations in experimental designs, and test conditions applied. Suppression observed in treatment $\mathrm{N} 2 \mathrm{~B} 1$ could be the result of priming because plants usually switch to a primed state of enhanced defense after they were affected by a pathogen. For many plant hosts, it has been shown that rhizobacteria potentiate the plant defense upon subsequent pathogen recognition, and many authors recognize the value of priming in field applications (Conrath et al. 2006; Pozo et al. 2008; Van Wees et al. 2008).

Pathogenic and nonpathogenic agrobacteria can similarly induce early plant defense responses upon PAMP recognition (Ditt et al. 2006; Zipfel 2009). However, upon transformation and expression of the T-DNA tumorigenic genes, the host defense is silenced, enabling initiation of tumor growth (Veena et al. 2003). Our splitroot experiment (treatment N2B1) showed that the pathogenic A. tumefaciens strain systemically suppressed the reproduction of $M$. ethiopica nematodes when physically separated, which could indicate the involvement of defense priming. The systemic plant defense response also was evident in treatments where part of the tomato root was primed with the heat-killed pathogenic agrobacteria or nonpathogenic E.coli. The extent of M. ethiopica egg count reduction was greater in treatments with a heat-killed than with a live pathogenic $A$. tumefaciens strain. PAMP molecules such as bacterial lipopolysaccharide (LPS) are known to activate the PTI response (Mishina and Zeier 2007). On its own, E. coli O157:H7 is capable of inducing a strong plant response in Arabidopsis thaliana (Seo and Matthews 2012) and, similarly, Arabidopsis activates defenses toward mutant agrobacteria impaired in attachment (Ditt et al. 2006) or upon recognition of peptide elf 26 derived from the $\mathrm{N}$-terminus of bacterial elongation factor Tu (Zipfel et al. 2006).

Unhindered penetration of $M$. ethiopica nematode juveniles into the roots. The PTI defense involves, among other things, an extensive oxidative burst that targets invading pathogens, and accelerated callose deposition onto cell walls. Based on our results from treatment N2B1, fewer galls and fewer egg masses could result from hindered $M$. ethiopica juvenile penetration due to active plant defenses or inability of juveniles to establish feeding sites and, eventually, galls. We confirmed that agrobacteria did not affect $M$. ethiopica penetration into the roots. Callose deposition, known as one of the first and basal defense mechanisms to prevent pathogens from spreading, is reportedly ineffective against lytic enzymes secreted by invading infective juveniles (Kaplan and Keen 1980). Not only RKN but also pathogenic agrobacteria secrete catalases to neutralize the ROS outburst (Xu and Pan 2000).

$M$. ethiopica reproduction was stimulated by pathogenic Agrobacterium tumefaciens but tumor formation was prevented. A stimulating effect of Agrobacterium tumefaciens on M. ethiopica reproduction on infested tomato plants was recorded in treatment N1B2 from the pot (90 dpi) and split-root (45 dpi) experiments. However, tumor growth was absent only in N1B2. We hypothesize that $M$. ethiopica can modify the plant response for allowing feeding site formation, as described previously (Smant and Jones 2011), and that the altered physiology of plants does not allow the initiation of tumors by A. tumefaciens. Plant hormonal balance has been suggested to play a significant role in the ability of agrobacteria to transform plant cells and cause tumor growth (Deeken et al. 2006; Veselov et al. 2003). Contrary to this notion, our results on root tumor incidence suggest a stimulated tumor growth rate in the presence of $M$. ethiopica nematodes but only when tumorigenesis is initiated prior to $M$. ethiopica inoculation. Faster tumor growth also was noticed by Dhanvantari et al. (1975) on young peach trees, where crown gall appeared on all trees after 150 days but the rate of tumor appearance was higher on $\mathrm{RKN}$-infested peach trees. The speed of tumor growth might be attributed to higher transformation frequency mediated in an undetermined way by the nematodes, as proposed by Karimi et al. (2000).

Gene expression of PR1 was upregulated when $A$. tumefaciens reduced $M$. ethiopica reproduction. The split-root technique allows sampling of noninoculated root tissue for the determination of gene expression caused by a systemic plant response. Results from such experiments are also not influenced by volatiles that affect gene expression (e.g., plant ET and microbe-derived organic volatiles) (Farag et al. 2013). To prove the hypothesis that pathogenic agrobacteria prime tomato, we focused on the expression of genes controlled by JA/ET signalization pathway that have been implicated in defense priming and ISR activation with other rhizobacteria.

The majority of target genes had been either downregulated or not affected, which is not unexpected in compatible plant-pathogen interactions (Schaff et al. 2007). However, we showed that plants exhibited an induced systemic downregulation of the ACS6 gene within minutes after the pathogenic C58 strain was inoculated. The nonpathogenic strain $\mathrm{C} 58 \mathrm{C} 1$, lacking the pTi plasmid, did not

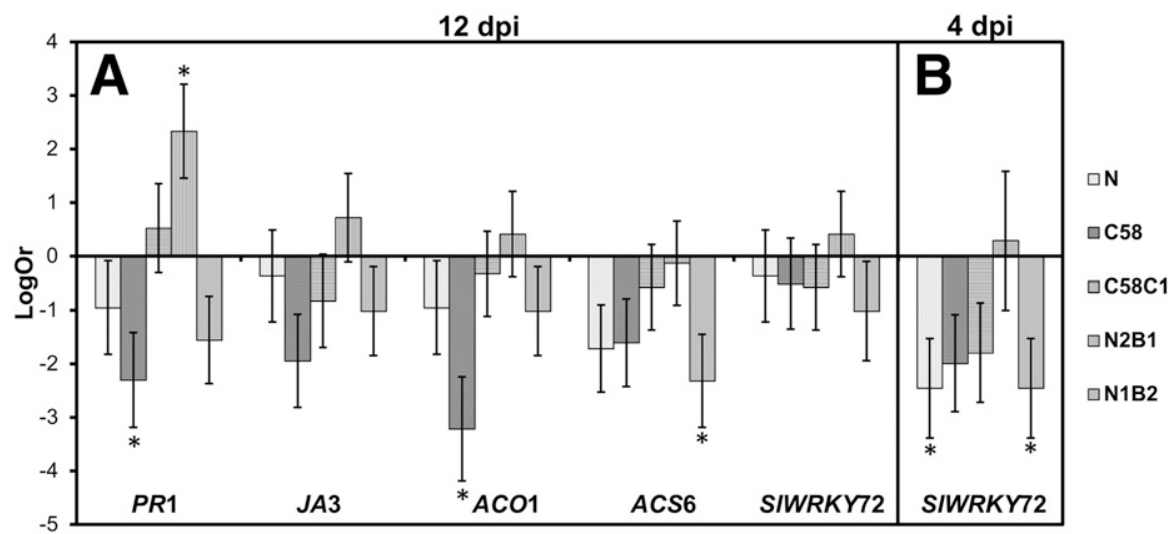

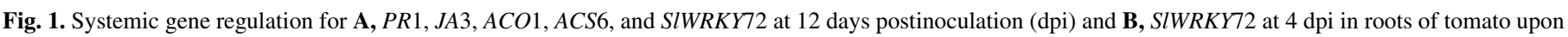

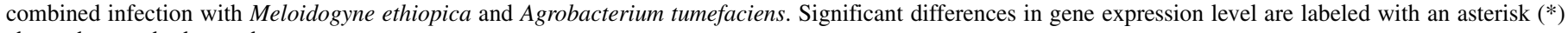
above the standard error bar. 
provoke a similar plant response, suggesting the importance of the pTi in early pathogenesis.

$M$. ethiopica did not induce a strong plant response. Gene expression of transcription factor $S l W R K Y 72$ was downregulated at the time of $M$. ethiopica penetration into the roots (4 dpi). WRKY transcription factors are associated with transcriptional reprogramming in plant immunity (Eulgem and Somssich 2007). A variant WRKY72 in tomato (SlWRKY72) was found to contribute to basal (PTI) defense against RKN and potato aphids and also linked to Mi-1-mediated resistance in tomato (Bhattarai et al. 2010). Gene expression of $S l W R K Y 72$ was not upregulated, as would be expected at the site of infection (Bhattarai et al. 2010). We hypothesize that this is the result of RKN early action to inhibit or modify the PTI response. The detection of ACS6 downregulation 4 days after strain C58 was inoculated onto M. ethiopica-infected roots (N1B2) and not sooner may support this hypothesis. This suggests a slower-rather than otherwise fast-plant response to pathogenic Agrobacterium that was modified by RKN.

Our results suggest that SA is responsible for the observed antagonism between Agrobacterium and Meloidogyne spp. and not JA, as suggested for many ISR-activating rhizobacteria (Cooper et al. 2005; Martinuz et al. 2013). Gene $P R 1$, a marker gene of SA pathway activation and SAR induction (Ward et al. 1991), showed significant upregulation in roots physically separated from A. tumefaciensinfected roots subsequently challenged with $M$. ethiopica nematodes (N2B1 treatment). It was only in this treatment that $P R 1$ was upregulated. It has been reported that flagellin and purified bacterial LPS can induce expression of $P R 1$ and activation of the SA defense pathway (Mishina and Zeier 2007; Seo and Matthews 2012). Interestingly, the JA-induced gene JA3, a synonym for the MYC2 transcription factor gene in tomato, was downregulated in the roots inoculated with C58 but upregulated in N2B1 (Fig. 1A). This indicates that priming with $\mathrm{C} 58$ resulted not only in $P R 1$ upregulation after M. ethiopica recognition but also in a derepression of MYC2 that was otherwise downregulated by C58. Two important findings are highlighted in this study: plants can be primed with pathogenic agrobacteria for enhanced defense against the RKN, and RKN do not prime plants for increased Agrobacterium infections. Our results suggest that the pathogenic agrobacteria activated PTI, which resulted in priming of the host defenses. Priming is manifested in a fast, strong defense response upon subsequent pathogen infection (Conrath et al. 2006), which we observed as the upregulation of $P R 1$ in systemic root tissue upon $M$. ethiopica recognition. The second significant finding is that RKN do not prime plants for Agrobacterium infection. For a long time, the PTI response in plant-RKN interactions was questionable. Recently, Lin et al. (2016) proposed that nematodes may secrete currently unknown effectors for the suppression of the host antioxidant system involved in immune response. This would explain why a subsequent infection with $A$. tumefaciens did not result in an increased defense activation.

The conclusion that the SA pathway is responsible for the observed suppression in the studied Agrobacterium-Meloidogyne pathosystem may allow for the development of appropriate control agents for crop protection. Plant defense mediated by SA and JA is effective in RKN management (Cooper et al. 2005; Fujimoto et al. 2011); however, only SA arrests tumor growth in crown gall disease (Anand et al. 2008). Our results suggest that foliar treatments targeting SAR activation might offer a better disease and pest management strategy in the simultaneous control of pathogenic agrobacteria and RKN.

\section{ACKNOWLEDGMENTS}

We thank a research group of X. Nesme (Ecologie Microbienne, INRA, Lyon, France) for supplying strains C58 and C58C1, B. Grubar for technical support in qPCR, and H. J. Schroers for critical review of the manuscript. This research was supported by the Slovenian Research Agency (grant agreement 1000-06-310203 and research programs P4-0133 and P4-0072) and FP7 Project CropSustaIn (FP7-REGPOT-CT2012-316205).

\section{LITERATURE CITED}

Aballay, E., Ordenes, P., Mårtensson, A., and Persson, P. 2013. Effects of rhizobacteria on parasitism by Meloidogyne ethiopica on grapevines. Eur. J. Plant Pathol. 135:137-145.

Abramovitch, R. B., Anderson, J. C., and Martin, G. B. 2006. Bacterial elicitation and evasion of plant innate immunity. Nat. Rev. Mol. Cell Biol. 7: 601-611.

Adam, M., Westphal, A., Hallmann, J., and Heuer, H. 2014. Specific microbial attachment to root knot nematodes in suppressive soil. Appl. Environ. Microbiol. 80:2679-2686.

Altschul, S. F., Gish, W., Miller, W., Myers, E. W., and Lipman, D. J. 1990. Basic local alignment search tool. J. Mol. Biol. 215:403-410.

Anand, A., Uppalapati, S. R., Ryu, C. M., Allen, S. N., Kang, L., and Tang, Y. 2008. Salicylic acid and systemic acquired resistance play a role in attenuating crown gall disease caused by Agrobacterium tumefaciens. Plant Physiol. 146:703-715.

Aydınlı, G., Mennan, S., Devran, Z., Širca, S., and Urek, G. 2013. First report of the root-knot nematode Meloidogyne ethiopica on tomato and cucumber in Turkey. Plant Dis. 97:1262.

Bakker, P. A. H. M., Pieterse, C. M. J., and Van Loon, L. C. 2007. Induced systemic resistance by fluorescent Pseudomonas spp. Phytopathology 97: 239-243.

Bhattarai, K. K., Atamian, H. S., Kaloshian, I., and Eulgem, T. 2010. WRKY72-type transcription factors contribute to basal immunity in tomato and Arabidopsis as well as gene-for-gene resistance mediated by the tomato $R$ gene $M i-1$. Plant J. 63:229-240.

Byrd, D. W., Jr., Kirkpatrick, T., and Barker, K. R. 1983. An improved technique for clearing and staining plant tissue for detection of nematodes. J. Nematol. 15:142-143.

Carneiro, R. M.. D. G., Almeida, M. R. A., Cofcewicz, E. T., Magunacelaya, J. C., and Aballay, E. 2007. Meloidogyne ethiopica, a major root-knot nematode parasitising Vitis vinifera and other crops in Chile. Nematology 9:633-639.

Conceição, I. L., Tzortzakakis, E. A., Gomes, P., Abrantes, I., and Da Cunha, M. J. 2012. Detection of the root-knot nematode Meloidogyne ethiopica in Greece. Eur. J. Plant Pathol. 134:451-457.

Conrath, U., Beckers, G. J. M., Flors, V., García-Agustín, P., Jakab, G., Mauch, F., Newman, M.-A., Pieterse, C. M. J., Poinssot, B., Pozo, M. J., Pugin, A., Schaffrath, U., Ton, J., Wendehenne, W., Zimmerli, L., and Mauch-Mani, B. 2006. Priming: Getting ready for battle. Mol. Plant-Microbe Interact. 19: 1062-1071.

Cooper, W. R., Jia, L., and Goggin, L. 2005. Effects of jasmonate induced defences on root-knot nematode infection of resistant and susceptible tomato cultivars. J. Chem. Ecol. 31:1953-1967.

Costechareyre, D., Rhouma, A., Lavire, C., Portier, P., Chapulliot, D., Bertolla, F., Boubaker, A., Dessaux, Y., and Nesme, X. 2010. Rapid and efficient identification of Agrobacterium species by recA allele analysis. Microb. Ecol. 60:862-872.

Davis, E. L., Hussey, R. S., Mitchum, M. G., and Baum, T. J. 2008. Parasitism proteins in nematode-plant interactions. Curr. Opin. Plant Biol. 11:360-366.

Deeken, R., Engelmann, J. C., Efetova, M., Czirjak, T., Müller, T., Kaiser, W. M., Tietz, O., Krischke, M., Mueller, M. J., Palme, K., Dandekar, T., and Hedrich, R. 2006. An integrated view of gene expression and solute profiles of Arabidopsis tumors: A genome-wide approach. Plant Cell 18:3617-3634.

De Neve, J., Thas, O., Ottoy, J.-P., and Clement, L. 2013. An extension of the Wilcoxon-Mann-Whitney test for analysing RT-qPCR data. Stat. Appl. Genet. Mol. Biol. 12:333-346.

Dhanvantari, B. N., Johnson, P. W., and Dirks, V. A. 1975. The role of nematodes in crown gall infection of peach in southwestern Ontario. Plant Dis. Rep. 59:109-112.

Ditt, R. F., Kerr, K. F., de Figueiredo, P., Delrow, J., Comai, L., and Nester, E. W. 2006. The Arabidopsis thaliana transcriptome in response to Agrobacterium tumefaciens. Mol. Plant-Microbe Interact. 19:665-681.

Ditt, R. F., Nester, E. W., and Comai, L. 2005. The plant cell defense and Agrobacterium tumefaciens. FEMS Microbiol. Lett. 247:207-213.

Dubreuil, G., Deleury, E., Magliano, M., Jaouannet, M., Abad, P., and Rosso, M. N. 2011. Peroxiredoxins from the plant parasitic root-knot nematode, Meloidogyne incognita, are required for successful development within the host. Int. J. Parasitol. 41:385-396.

El-Beltagi, H. S., Kesba, H. H., Abdel-Alim, A. I., and Al-Sayed, A. A. 2011. Effect of root-knot nematode and two species of crown gall on antioxidant activity of grape leaves. Afr. J. Biotechnol. 10:12202-12210.

El-Sherif, A. G., and Elwakil, M. A. 1991. Interaction between Meloidogyne incognita and Agrobacterium tumefaciens or Fusarium oxysporum f. sp. lycopersici on tomato. J. Nematol. 23:239-242.

Epstein, L., Kaur, S., McKenna, J. R., Grant, J. A., Olson, W., and Reil, W. O. 2008. Crown gall can spread between walnut trees in nurseries and reduce future fields. Calif. Agric. 62:111-115. 
Eulgem, T., and Somssich, I. E. 2007. Networks of WRKY transcription factors in defense signaling. Curr. Opin. Plant Biol. 10:366-371.

Fakhouri, W. D., Khlaif, H., and Abu-Gharbeih, W. I. 1996. Interaction between Meloidogyne javanica and Agrobacterium tumefaciens on tomato plants. Pak. J. Nematol. 14:49-54.

Farag, M. A., Zhang, H., and Ryn, C.-M. 2013. Dynamic chemical communication between plants and bacteria through airborne signals: Induced resistance by bacterial volatiles. J. Chem. Ecol. 39:1007-1018.

Fernández, I., Merlos, M., López-Ráez, J. A., Martínez-Medina, A., Ferrol, N., Azcón, C., Bonfante, P., Flors, V., and Pozo, M. J. 2014. Defense related phytohormones regulation in arbuscular mycorrhizal symbioses depends on the partner genotypes. J. Chem. Ecol. 40:791-803.

Fowler, J. H., Narváez-Vásquez, J., Aromdee, D. N., Pautot, V., Holzer, F. M., and Walling, L. L. 2009. Leucine aminopeptidase regulates defense and wound signaling in tomato downstream of jasmonic acid. Plant Cell 21:1239-1251.

Fujimoto, T., Tomitaka, Y., Abe, H., Tsuda, S., Futai, K., and Mizukubo, T. 2011. Expression profile of jasmonic acid induced genes and the induced resistance against the root knot nematode (Meloidogyne incognita) in tomato plants (Solanum lycopersicum) after foliar treatment with methyl jasmonate. J. Plant Physiol. 168:1084-1097.

Griffin, G. D., Anderson, J. L., and Jorgenson, E. C. 1968. Interaction of Meloidogyne hapla and Agrobacterium tumefaciens in relation to raspberry cultivars. Discov. Rep. 52:492-493.

Hallmann, J., Davies, K. G., and Sikora, R. 2009. Biological control using microbial pathogens, endophytes and antagonists. Pages 380-411 in: RootKnot Nematodes. R. N. Perry, M. Moens, and J. L. Starr, eds. CAB International, Wallingford, UK.

Hallmann, J., Quadt-Hallmann, A., Miller, W. G., Sikora, R. A., and Lindow, S. E. 2001. Endophytic colonization of plants by the biocontrol agent Rhizobium etli G12 in relation to Meloidogyne incognita infection. Biol. Control 91:415-422.

Hellemans, J., Mortier, G., De Paepe, A., Speleman, F., and Vandesompele, J. 2007. qBase relative quantification framework and software for management and automated analysis of real-time quantitative PCR data. Genome Biol. 8:R19.

Hussey, R. S., and Barker, K. R. 1973. A comparison of methods of collecting inocula of Meloidogyne spp. including a new technique. Plant Dis. Rep. 57: 1025-1028.

Jaouannet, M., Magliano, M., Arguel, M. J., Gourgues, M., Evangelisti, E., Abad, P., and Rosso, M. N. 2013. The root-knot nematode calreticulin MiCRT is a key effector in plant defense suppression. Mol. Plant-Microbe Interact. 26:97-105.

Jaubert, S., Ledger, T. N., Laffaire, J. B., Piotte, C., Abad, P., and Rosso, M.-N. 2002. Direct identification of stylet secreted proteins from root-knot nematodes by a proteomic approach. Mol. Biochem. Parasitol. 121:205-211.

Jones, J. D. G., and Dangl, J. L. 2006. The plant immune system. Nature 444: 323-329.

Journot-Catalino, N., Somssich, I. E., Roby, D., and Kroj, T. 2006. The transcription factors WRKY11 and WRKY17 act as negative regulators of basal resistance in Arabidopsis thaliana. Plant Cell 18:3289-3302.

Kaplan, D. T., and Keen, N. T. 1980. Mechanisms conferring plant incompatibility to nematodes. Rev. Nematol. 3:123-134.

Karimi, M., Van Montagu, M., and Gheysen, G. 2000. Nematodes as vectors to introduce Agrobacterium into plant roots. Mol. Plant Pathol. 1:383-387.

Kennedy, B. W., and Alcorn, S. M. 1980. Estimates of U.S. crop losses to prokaryote plant pathogens. Plant Dis. 64:674-676.

Kohl, M. 2007. SLqPCR: Functions for Analyzing of Real-Time Quantitative PCR Data at SIRS-Lab GmbH. SIRS-Lab GmbH, Jena, Germany.

Lamovšek, J., Gerič Stare, B., and Urek, G. 2014. Isolation of non-pathogenic Agrobacterium spp. biovar 1 from agricultural soils in Slovenia. Phytopathol. Mediterr. 53:130-139.

Lee, C. W., Efetova, M., Engelmann, J. C., Kramell, R., Wasternack, C., Ludwig-Müller, J., Hedrich, R., and Deeken, R. 2009. Agrobacterium tumefaciens promotes tumor induction by modulating pathogen defense in Arabidopsis thaliana. Plant Cell 21:2948-2962.

Li, Q., Guo, R.-J., Li, S.-D., Li, S.-F., and Wang, H.-Q. 2015. Determination of tumorigenic Agrobacterium density in soil by real-time PCR assay and its effect on crown gall disease severity. Eur. J. Plant Pathol. 142:25-36.

Lin, B., Zhuo, K., Chen, S., Hu, L., Sun, L., Wang, X., Zhang, L. H., and Liao, J. 2016. A novel nematode effector suppresses plant immunity by activating host reactive oxygen species-scavenging system. New Phytol. 209:1159-1173.

Løvdal, T., and Lillo, C. 2009. Reference gene selection for quantitative realtime PCR normalization in tomato subjected to nitrogen, cold, and light stress. Anal. Biochem. 387:238-242.

Mantelin, S., Bhattarai, K. K., Jhaveri, T. Z., and Kaloshian, I. 2013. Mi-1mediated resistance to Meloidogyne incognita in tomato may not rely on ethylene but hormone perception through ETR3 participates in limiting nematode infection in a susceptible host. PLoS One 8:e63281.

Martinuz, A., Schouten, A., and Sikora, R. A. 2013. Post-infection development of Meloidogyne incognita on tomato treated with the endophytes
Fusarium oxysporum strain Fo162 and Rhizobium etli strain G12. BioControl 58:95-104.

McClure, M. A., Kruk, T. H., and Misaghi, I. 1973. A method for obtaining quantities of clean Meloidogyne eggs. J. Nematol. 5:230.

Mishina, T. E., and Zeier, J. 2007. Pathogen-associated molecular pattern recognition rather than development of tissue necrosis contributes to bacterial induction of systemic acquired resistance in Arabidopsis. Plant J. 50:500-513.

Mougel, C., Cournoyer, B., and Nesme, X. 2001. Novel tellurite-amended media and specific chromosomal and Ti plasmid probes for direct analysis of soil populations of Agrobacterium biovars 1 and 2. Appl. Environ. Microbiol. 67:65-74.

Nicol, J. M., Turner, S. J., Coyne, D. L., and Den Nijs, L. 2011. Current nematode threats to world agriculture. Pages 21-43 in: Genomics and Molecular Genetics of Plant-Nematode Interactions. J. Jones, G. Gheysen, and C. Fenoll, eds. Springer, London.

Orion, D., and Zutra, D. 1971. The effect of the root-knot nematode on the penetration of crown gall bacteria into almond roots. Isr. J. Agric. Res. 21: 27-29.

Pozo, M. J., Van der Ent, S., Van Loon, L. C., and Pieterse, C. M. J. 2008. Transcription factor MYC2 is involved in priming for enhanced defense during rhizobacteria-induced systemic resistance in Arabidopsis thaliana. New Phytol. 180:511-523.

Radwan, M. A., Farrag, S. A. A., Abu-Elamayem, M. M., and Ahmed, N. S. 2012. Biological control of the root-knot nematode, Meloidogyne incognita on tomato using bioproducts of microbial origin. Appl. Soil Ecol. 56:58-62.

Rubio-Cabetas, M. J., Minot, J. C., Voisin, R., and Esmenjaud, D. 2001. Interaction of root-knot nematodes (RKN) and the bacterium Agrobacterium tumefaciens in roots of Prunus cerasifera: Evidence of the protective effect of the $M a$ RKN resistance genes against expression of crown gall symptoms. Eur. J. Plant Pathol. 107:433-441.

Schaad, N. W., Jones, J. B., and Chun, W. 2001: Pages 17-35 in: Laboratory Guide for Identification of Plant-Pathogenic Bacteria, 3rd ed. American Phytopathological Society Press, St. Paul, MN.

Schaff, J. E., Nielsen, D. M., Smith, C. P., Scholl, E. H., and Bird, D. M. 2007. Comprehensive transcriptome profiling in tomato reveals a role for glycosyltransferase in $M i$-mediated nematode resistance. Plant Physiol. 144:1079-1092.

Seo, S., and Matthews, K. R. 2012. Influence of the plant defense response to Escherichia coli $\mathrm{O} 157: \mathrm{H} 7$ cell surface structures on survival of that enteric pathogen on plant surfaces. Appl. Environ. Microbiol. 78:5882-5889.

Siddiqui, Z. A., Baghel, G., and Akhtar, M. S. 2007. Biocontrol of Meloidogyne javanica by Rhizobium and plant growth-promoting rhizobacteria on lentil. World J. Microbiol. Biotechnol. 23:435-441.

Širca, S., Urek, G., and Karssen, G. 2004. First report of the root-knot nematode Meloidogyne ethiopica on tomato in Slovenia. Plant Dis. 88:680.

Smant, G., and Jones, J. 2011. Suppression of plant defences by nematodes. Pages 273-286 in: Genomics and Molecular Genetics of Plant-Nematode Interactions. J. Jones, G. Gheysen, and C. Fenoll, eds. Springer, London.

Son, G. H., Wan, J., Kim, H. J., Nguyen, X. C., Chung, W. S., Hong, J. C., and Stacey, G. 2012. Ethylene-responsive element-binding factor 5, ERF5, is involved in chitin-induced innate immunity response. Mol. Plant-Microbe Interact. 25:48-60

Song, W., Ma, X., Tan, H., and Zhou, J. 2011. Abscisic acid enhances resistance to Alternaria solani in tomato seedlings. Plant Physiol. Biochem. 49:693-700

Strajnar, P., Širca, S., Knapič, M., and Urek, G. 2011. Effect of Slovenian climatic conditions on the development and survival of root-knot nematode Meloidogyne ethiopica. Eur. J. Plant Pathol. 129:81-88.

Strajnar, P., Širca, S., Urek, G., Šircelj, H., Železnik, P., and Vodnik, D. 2012. Effect of Meloidogyne ethiopica parasitism on water management and physiological stress in tomato. Eur. J. Plant Pathol. 132:49-57.

Süle, S., Lehoczky, J., Jenser, G., Nagy, P., and Burr, T. J. 1995. Infection of grapevine roots by Agrobacterium vitis and Meloidogyne hapla. J. Phytopathol. 143:169-171.

Untergasser, A., Cutcutache, I., Koressaar, T., Ye, J., Faircloth, B. C., Remm, M., and Rozen, S. G. 2012. Primer3-New capabilities and interfaces. Nucleic Acids Res. 40:e115.

Van der Ent, S., Van Wees, S. C. M., and Pieterse, C. M. J. 2009. Jasmonate signalling in plant interactions with resistance-inducing beneficial microbes. Phytochemistry 70:1581-1588.

Vandesompele, J., De Preter, K., Pattyn, F., Poppe, B., Van Roy, N., De Paepe, A., and Speleman, F. 2002. Accurate normalization of real-time quantitative RT-PCR data by geometric averaging of multiple internal control genes. Genome Biol. 3:research0034.1. doi:10.1186/gb-2002-3-7-research0034

Van Wees, S. C. M., Van der Ent, S., and Pieterse, C. M. J. 2008. Plant immune responses triggered by beneficial microbes. Curr. Opin. Plant Biol. 11:443-448.

Veena, Jiang, H., Doerge, R. W., and Gelvin, S. B. 2003. Transfer of T-DNA and Vir proteins to plant cells by Agrobacterium tumefaciens induces expression of host genes involved in mediating transformation and suppresses host defense gene expression. Plant J. 35:219-236. 
Veselov, D., Langhans, M., Hartung, W., Aloni, R., Feussner, I., Götz, C., Veselova, S., Schlomski, S., Dickler, C., Bächmann, K., and Ullrich, C. I. 2003. Development of Agrobacterium tumefaciens C58-induced plant tumors and impact on host shoots are controlled by a cascade of jasmonic acid, auxin, cytokinin, ethylene and abscisic acid. Planta 216:512-522.

Ward, E. R., Uknes, S. J., Williams, S. C., Dincher, S. S., Wiederhold, D. L., Alexander, D. C., Ahl-Goy, P., Metraux, J. P., and Ryals, J. A. 1991. Coordinate gene activity in response to agents that induce systemic acquired resistance. Plant Cell 3:1085-1094.

Weyman, P. D., Pan, Z., Feng, Q., Gilchrist, D. G., and Bostock, R. M. 2006. A circadian rhythm-regulated tomato gene is induced by arachidonic acid and Phytophthora infestans infection. Plant Physiol. 140:235-248.

Wu, Y., Zhang, D., Chu, J. Y., Boyle, P., Wang, Y., Brindle, I. D., De Luca, V., and Després, C. 2012. The Arabidopsis NPR1 protein is a receptor for the plant defense hormone salicylic acid. Cell Rep. 1:639-647.
Xie, D. X., Feys, B. F., James, S., Nieto-Rostro, M., and Turner, J. G. 1998. COI1: An Arabidopsis gene required for jasmonate-regulated defense and fertility. Science 280:1091-1094.

Xu, X. Q., and Pan, S. Q. 2000. An Agrobacterium catalase is a virulence factor involved in tumorigenesis. Mol. Microbiol. 35:407-414.

Yan, Z., Reddy, M. S., Ryu, C.-M., McInroy, J. A., Wilson, M., and Kloepper, J. W. 2002. Induced systemic protection against tomato late blight elicited by plant growth-promoting rhizobacteria. Phytopathology 92:1329-1333.

Zipfel, C. 2009. Early molecular events in PAMP-triggered immunity. Curr. Opin. Plant Biol. 12:414-420.

Zipfel, C., Kunze, G., Chincilla, D., Caniard, A., Jones, J. D. G., Boller, T., and Felix, G. 2006. Perception of bacterial PAMP EF-Tu by the receptor EFR restricts Agrobacterium-mediated transformation. Cell 125:749-760.

Zutra, D., and Orion, D. 1982. Crown gall bacteria (Agrobacterium radiobacter var. tumefaciens) on cotton roots in Israel. Plant Dis. 66:1200-1201. 